WORKING PAPER 221

International monetary policy spillovers through the bank funding channel 
The Working Paper series of the Oesterreichische Nationalbank is designed to disseminate and to provide a platform for discussion of either work of the staff of the OeNB economists or outside contributors on topics which are of special interest to the OeNB. To ensure the high quality of their content, the contributions are subjected to an international refereeing process. The opinions are strictly those of the authors and do in no way commit the OeNB.

The Working Papers are also available on our website (http://www.oenb.at) and they are indexed in RePEc (http://repec.org/).

Publisher and editor

Editorial Board

of the Working Papers

Coordinating editor

Design

DVR 0031577

ISSN 2310-5321 (Print)

ISSN 2310-533X (Online)

(C) Oesterreichische Nationalbank, 2018. All rights reserved.

Oesterreichische Nationalbank

Otto-Wagner-Platz 3, 1090 Vienna, Austria

PO Box 61, 1011 Vienna, Austria

www.oenb.at

oenb.info@oenb.at

Phone (+43-1) 40420-6666

Fax (+43-1) 40420-046698

Doris Ritzberger-Grünwald, Ernest Gnan, Martin Summer

Martin Summer

Communications and Publications Division 


\title{
International monetary policy spillovers through the bank funding channel
}

\author{
Peter Lindner ${ }^{\mathrm{a}}$ \\ Axel Loeffler ${ }^{\mathrm{b}}$ \\ Esther Segalla ${ }^{c}$ \\ Guzel Valitova $^{\mathrm{d}}$ \\ Ursula Vogel ${ }^{\mathrm{e}}$
}

\begin{abstract}
In this paper, we examine the international transmission of monetary policies of major advanced economies (US, UK, euro area) through banks in Austria and Germany. In particular, we compare the role of banks' funding structure, broken down by country of origin as well as by currency denomination, in the international transmission of monetary policy changes to bank lending. We find weak evidence for inward spillovers. The more a bank is funded in US dollars, the more its domestic real sector lending is affected by monetary policy changes in the US. This effect is more pronounced in Germany than in Austria. We do not find evidence for outward spillovers of euro area monetary policy through a bank funding channel.
\end{abstract}

Keywords: monetary policy spillover, global banks, bank funding channel.

JEL-Classification: E52, F33, G21

\footnotetext{
apeter.lindner@oenb.at, Oesterreichische Nationalbank, Economic Studies Division, Otto-Wagner-Platz 3, 1090 Vienna, Austria; baxel.loeffler@bundesbank.de, Deutsche Bundesbank, Directorate General Financial Stability, Wilhelm-Epstein-Str. 14, 60431 Frankfurt; 'esther.segalla@oenb.at, Oesterreichische Nationalbank, Economic Studies Division, Otto-Wagner-Platz 3, 1090 Vienna, Austria; dvalitovaguzel@gmail.com; 'eursula.vogel@bundesbank.de, Deutsche Bundesbank, Directorate General Financial Stability, Wilhelm-Epstein-Str. 14, 60431 Frankfurt. The paper benefitted from comments received from OeNB and Bundesbank staff, an anonymous referee and at the 2017 Banque de France/IBRN conference on 'Global Financial Linkages and Monetary Policy Transmission' in Paris. The views expressed in this paper are those of the authors alone and do not necessarily reflect the policy or positions of the Oesterreichische Nationalbank, the Deutsche Bundesbank or the Eurosystem.
} 


\section{Non-technical summary}

\section{Research question}

This paper examines whether monetary policy changes in major advanced economies (US, UK, and the euro area) are transmitted through the credit extension of banks in Austria and Germany. In particular, the role of banks' funding structure, broken down by country of origin as well as by currency denomination, for the international transmission of monetary policy changes to bank lending is compared.

This paper is a contribution to the IBRN (International Banking Research Network) ${ }^{1}$ project on "The International Transmission of Monetary Policy".

\section{Contribution}

Against the background of current monetary policy and the relevance of internationally active banks, a growing literature has been exploring the international transmission of monetary policy. Existing studies find that bank characteristics, for instance the geographical funding structure, play an important role for the international transmission of monetary policy. At the same time, other studies show that internationally active banks transfer funds internationally to capitalise on favourable foreign funding conditions. Our study compares the role of the geographical and the currency funding structure for the international transmission of monetary policy changes to the credit extension by banks in Austria and Germany.

\section{Results}

In our study on banks in Austria and Germany (sample period: 2005-2015) we find only weak evidence for the international transmission of monetary policy through the bank funding channel. Empirical results for the inward transmission appear to indicate that US monetary policy might affect domestic lending to the non-financial private sector the more a bank funds its operations in US dollars (but not from the US). This effect is more pronounced in Germany than in Austria. However, although statistically significant, the economic impact is negligible. For direct cross-border credit extension of banks in Austria and Germany we do not find a robust impact of funding structures.

\footnotetext{
${ }^{1}$ For more information see: https://www.newyorkfed.org/ibrn.
} 


\section{Introduction}

After the global financial crisis, the monetary policy rates of major advanced economies were slashed to unprecedented low levels. To provide additional monetary stimulus, their central banks substantially increased their balance sheets. At the same time, the relevance of internationally active banks and global banking networks for the international transmission of shocks affecting credit extension in other countries has become apparent (see e.g. Hale et al. 2016, Puri et al. 2011). Against this background, a renewed interest in the (international) transmission of monetary policies has emerged (e.g. Hofmann and Takáts 2015, Bruno and Shin 2015, Cetorelli and Goldberg 2012, Fratzscher et al. 2016, Chen et al. 2016). In this paper, we analyze the funding structure of banks in Austria (AT) and Germany (DE) and examine how changes in the monetary policy of major reserve currency countries affect bank lending dependent on the funding structure of these banks.

The Austrian and German financial systems are predominantly bank-based, and both countries are home to several large international banks with significant exposures and liabilities abroad. ${ }^{2}$ Some of these internationally active banks receive a considerable share of funding from abroad and in foreign currency, and provide both foreign currency and euro-denominated credit to international borrowers. As to bank funding, we show that it makes a difference whether it is disaggregated by the country where it is from, or by the currency it is denominated in. While the major foreign funding currency is the US dollar, the country where most of banks' external funding is rooted is the UK, with London being the banking hub for Europe. Then, in our analyses, we test for the existence of an international bank funding channel ${ }^{3}$ by considering the heterogeneity in banks' funding structure. In particular, we study whether banks with strong funding roots in a country or a currency adjust their credit extension following a change in the monetary policy stance in that country. We study this transmission from both an inward and an outward perspective. While the former looks at how changes in the monetary policies of the US and the $\mathrm{UK}^{4}$ impact domestic lending of resident banks, the latter

\footnotetext{
${ }^{2}$ Although international banks represent a substantial share of both the Austrian and German banking systems, the major market share in lending is held by - primarily locally active - cooperative and savings banks.

${ }^{3}$ Through the bank funding channel, cheaper (more expensive) funding is translated into higher (lower) credit extension.

${ }^{4}$ We look at the US and the UK as they represent the main financial partners of the Austrian and German banking systems.
} 
looks at how changes in domestic monetary policy (the euro area) affect these banks' cross-border lending. ${ }^{5}$

While during 'normal' times central banks steer monetary policy rates by setting interest rates and providing scarce liquidity to banks, this has changed since the global financial crisis, when all major central banks started conducting some form of quantitative easing. Funding constraints of banks have been lifted by converting banks' illiquid assets into liquid central bank reserves. As a result, when central banks operate within an environment of excess liquidity the bank funding pattern is likely to be less important for the international transmission of monetary policy changes. Therefore, we examine whether monetary policy spillovers are attenuated when banks are flush with central bank reserves.

Our results provide only weak evidence for the transmission of monetary policy through the international bank funding channel. Inward transmission estimation results appear to indicate that US monetary policy might affect domestic lending to the non-financial private sector the more a bank funds its operations in US dollars, the major foreign funding currency in Germany. However, the economic impact is negligibly small. Overall Austrian banks rely less heavily on non-euro (area) foreign funding; hence it is not surprising that we observe less foreign monetary policy spillovers through this channel. We do not find evidence for outward spillovers of euro area monetary policy, although the major share of funding stems from the euro area and is denominated in euro. Overall, the statistically significant results are not very robust to changes in specifications and alternative measures of monetary policy. Hence, we conclude that currently bank funding structures do not play a major role for the international transmission of monetary policy through the Austrian and German banking system.

In the geographical dimension, our work most closely adds to the literature providing evidence for the international transmission of US monetary policy (e.g. Morais et al. 2018, Correa and Murry 2010). These studies, looking more closely at bank characteristics, find that geographical funding structure plays an important role for the international transmission of US monetary policy. For instance, Cetorelli and Goldberg (2012) and Braeuning and Ivashina (2017) show that when US monetary policy tightens, global banks use fund transfers from their foreign offices to capitalise on favourable foreign funding conditions. Avdjiev and Takáts (2016) show more generally that the currency composition of cross-border bank claims has a significant impact on

\footnotetext{
${ }^{5}$ A tightening of monetary policy could lead to an appreciation of the respective currency and, as a consequence, funding costs for those banks that hold liabilities in this currency would increase even further, with potential additional implications for credit supply. In our analyses, we are not able to account for this exchange rate effect and we may underestimate the change in funding costs for banks.
} 
the size, distribution and direction of cross-border monetary policy spillovers since 2012. However, no study has yet compared the country and the currency dimension of bank funding and its relevance for monetary policy transmission.

The remainder of the paper is structured as follows. In Section 2 we describe the data we use and provide some stylized facts. Section 3 outlines the empirical approach, and in Section 4 we present and discuss our results and some robustness checks. Section 5 concludes.

\section{Data and stylized facts}

\subsection{Data}

We use confidential bank-level data collected by the Oesterreichische Nationalbank (OeNB) and the Deutsche Bundesbank. The dataset comprises unconsolidated domestic exposures of banks located in Austria and Germany (including foreign-owned banks) as well as information on all of these banks' direct cross-border lending and funding positions by country and by currency. Data frequency is quarterly, and our sample period lasts from $2005 \mathrm{Q} 1$ to $2015 \mathrm{Q} 4$. $^{6}$ As we are looking at the international transmission of monetary policy, our sample is confined to major internationally active banks. We exclude special-purpose banks such as home loan banks, auto banks, investment banks or development banks. ${ }^{7}$ Balance sheet positions of banks merged with another bank during the observation period are aggregated and treated as one bank. ${ }^{8}$

We drop observations with changes in lending to the non-financial private sector (our main dependent variable) that are equal to or greater than 100 percent in absolute terms. Bank-specific controls include the core deposits ratio, capital ratio, net intragroup funding ratio and log of total assets. ${ }^{9}$ Appendix 1 provides an overview of variable definitions and Appendix 2 shows some summary statistics for AT and DE, respectively.

\footnotetext{
${ }^{6}$ Due to data constraints the sample period starts in 2005Q2 in AT.

${ }^{7}$ We also exclude banks showing structural breaks such as the selling of business units that leads to high volatility in the data.

${ }^{8}$ This approach of backward aggregation has been widely used in the literature. See, for example, Gambacorta and Shin (2016), Ehrmann et al. (2003), Gambacorta and Mistrulli (2004) and De Haas et al. (2015).

${ }^{9}$ To examine the role of net cross-border intragroup funding, we require data on lending between the parent bank in the home country and its affiliates abroad. As these data are not readily available, we proxy intragroup funding by relying on the affiliates' positions vis-à-vis the home banking system. For a similar approach, see Frey and Kerl (2015). A major limitation is that this proxy is available for domestic but not for foreign banks. For Austria net intragroup funding excludes positions of foreign subsidiaries located outside of Austria, but includes positions of respective foreign branches.
} 
Our main monetary policy measure is the change in the money market rate of those countries and currencies that are of the greatest relevance to Austrian and German banks (i.e. US, UK, euro area). The money market rate represents the most general indicator of the monetary policy stance irrespective of the liquidity situation in which the central bank operates. ${ }^{10}$ However, since the financial crisis, if not beforehand, the central banks of the major advanced economies have been operating at the zero lower bound. At the zero lower bound, central banks also have eased funding constraints of banks by providing excess central bank liquidity via outright purchases of longer term assets. In such an environment, the money market rate fails to signal a loosening of the monetary policy stance as the impact of these purchases is primarily reflected in long term interest rates. As the bank funding channel might be less relevant in an environment of abundant liquidity, particularly for banks holding a large amount of reserves, we use the banks' ratio of cash and central bank reserves over total assets (liquidity ratio) as an additional interaction variable to test for a conditional effect in the general transmission mechanism. ${ }^{11}$

\section{Figure 1: Money market rate in the euro area and (aggregate) liquidity ratio}
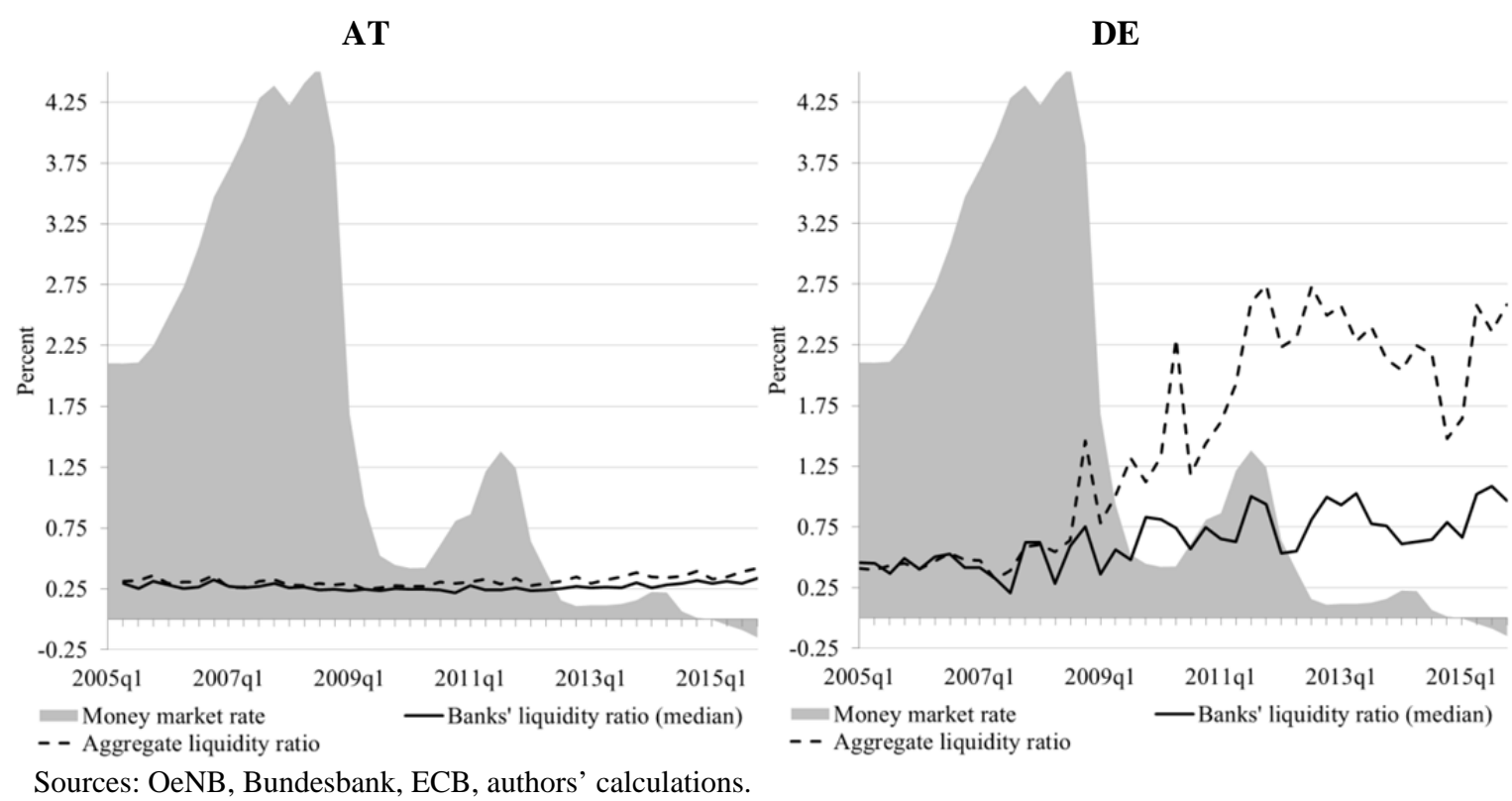

\footnotetext{
${ }^{10}$ In the UK, the US and the euro area, the central bank steers the interbank rate by setting main policy rates and providing liquidity according to the banking system's needs. The correlation between the main policy rate and the interbank rate is high. In recent years, however, those central banks have taken measures that increased excess liquidity. As a consequence, the relevant policy rate has changed from an interest rate at which the central bank provides liquidity to the interest rate at the lower bound of the corridor (deposit rate). The money market rate accounts for this shift and therefore serves as a suitable proxy of the 'true' policy rate.

${ }^{11}$ If banks decide to invest in low remunerated excess liquidity at the central bank opportunities to provide credit to the NFP at attractive interest rates seem to be low. With a subdued credit demand funding constraints are not a relevant factor to explain changes in the supply of credit.
} 
Figure 1 shows the increase in the liquidity ratio at the level of the banking system and individual banks. While in AT the degree of excess liquidity increased only modestly (and is generally much smaller in scale than for DE banks), in DE there is a significant increase in the amount of liquidity on banks' balance sheets since the money market rate has approached the zero lower bound.

\subsection{Stylised facts}

The Austrian and German banking systems are internationally integrated. The majority of foreign activities, however, are concentrated in a limited number of global banks. We restrict our analyses to these internationally active banks representing roughly 70 percent of total banking system assets for AT and 50 percent of total banking system assets for DE. Internationally active banks are principally all banks that have crossborder exposures or liabilities and therefore report the external banking statistics of AT or $\mathrm{DE}^{12}$ On aggregate, in both countries the share of foreign loans in total assets is higher than the share of external liabilities in total liabilities (see Figure 2).

\section{Figure 2: International integration of the Austrian and German international banks}

AT

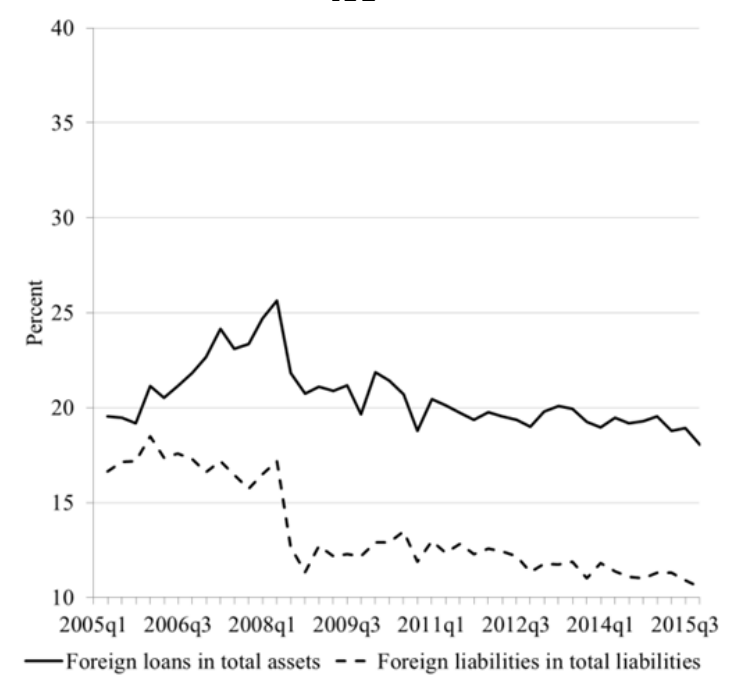

Sources: OeNB, Bundesbank, authors’ calculations.

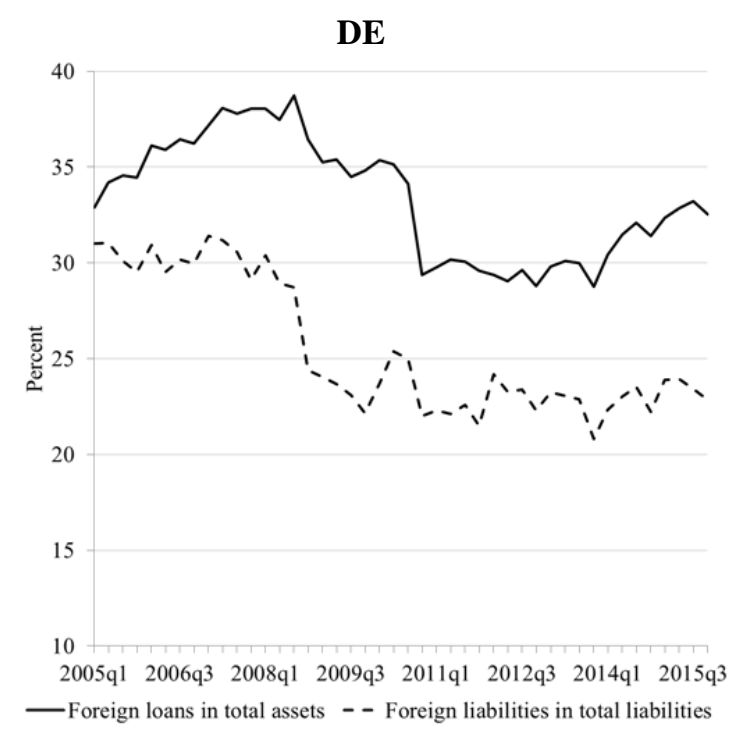

—-Foreign loans in total assets - - Foreign liabilities in total liabilities

\footnotetext{
${ }^{12}$ We further limit the sample to banks where lending to the private sector is a substantial line of business. We obtained information on this from the banks' websites.
} 
In the inward regressions the dependent variable is domestic lending to the nonfinancial private sector (NFPS). The banks in our sample provide in AT almost 60 percent and in DE almost 50 percent of all domestic outstanding lending to the NFPS.

On the funding side, we observe that a major share of external liabilities comes from the euro area and is denominated in euro (see Figure 3).

Figure 3: Split of external liabilities according to countries and to currencies (as of end 2015)
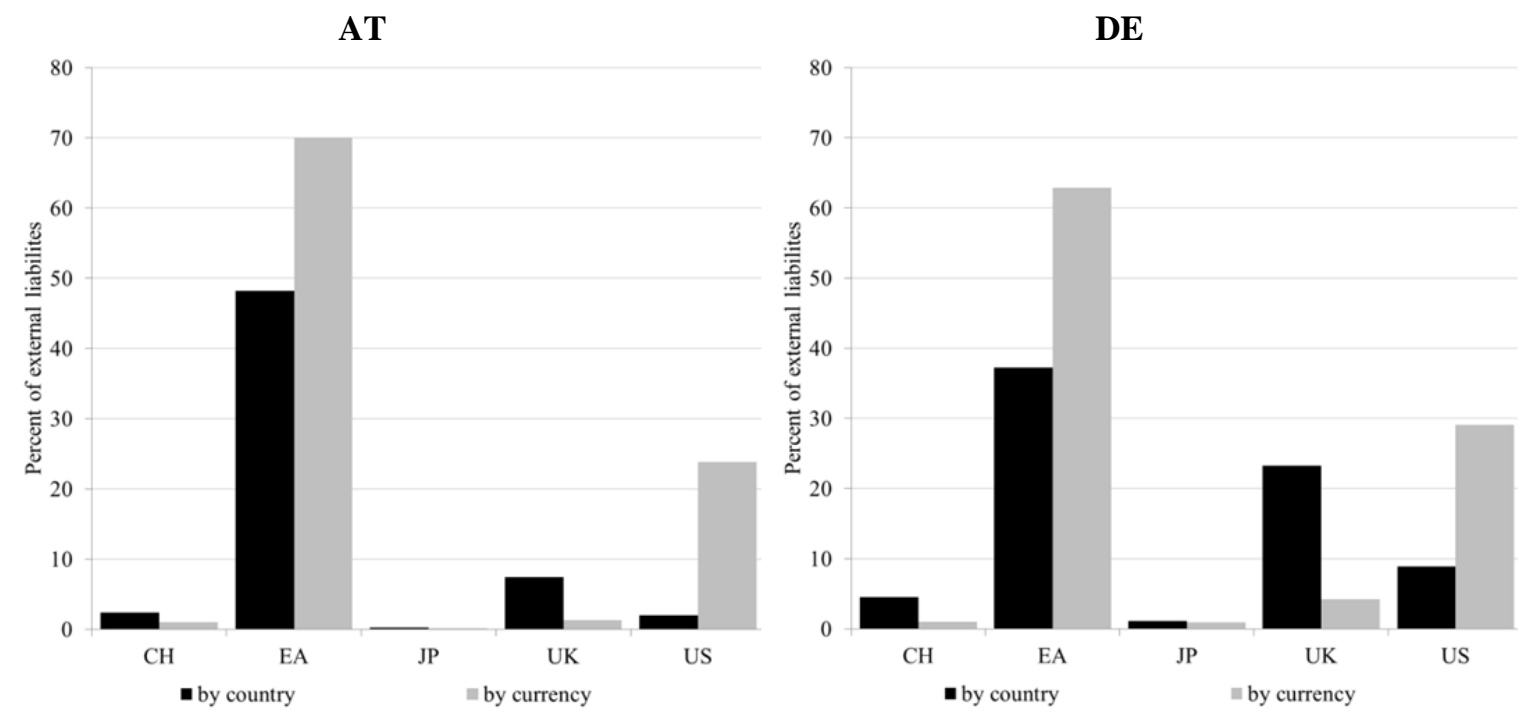

Source: OeNB, Bundesbank, authors’ calculations.

Beyond that, the largest shares of external liabilities are from the US, the UK, $\mathrm{CH}$ and JP. Together these four countries, however, only account for less than 55 percent of total external liabilities for DE and only 15 percent for AT. The shares of these countries' currencies are somewhat higher in AT and amount to a total of about 30 percent but only to about 35 percent in DE. For AT a substantial part of EUR external liabilities comes from deposits by non-euro area countries located predominantly in Eastern Europe. As Switzerland and Japan - both geographically and in terms of currency - are of less importance in the share of foreign funding, we focus on US and UK monetary policies.

Interestingly, while geographically the most important foreign country is the UK, followed by the US, the order is reversed when looking at the currency shares of funding in GBP and USD. Therefore, we deem it worthwhile to look more deeply into the role of the country and the currency dimension of banks' liabilities as a transmission channel of monetary policy changes. Spillover effects might differ due to various 
frictions in the respective markets. For instance, exchange rate changes affect net liabilities denominated in a foreign currency and hence potentially impact banks' lending capacity.

The euro area and the EUR represent the most important source and currency of bank funding in AT and DE. For AT the shares of funding from the euro area or in euro are around 90 percent of total liabilities and for DE close to 80 percent (Figure 4). In addition, the share of external loans in total assets is sizable and even larger than the share of external funding relative to total liabilities (Figure 2). Thus, from this observation we expect that the economic importance of an international bank funding channel is likely to be more pronounced with respect to the outward transmission of euro area monetary policy to Austrian and German banks’ external lending.

\section{Figure 4: Total liabilities from the euro area or denominated in euro (as of end- 2015)}

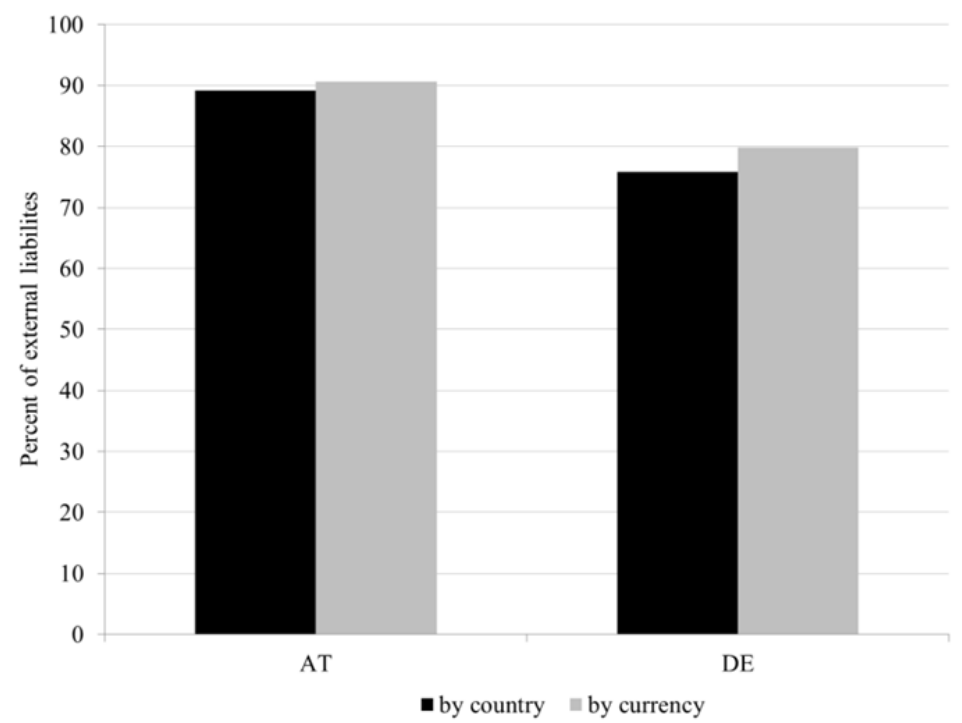

Sources: OeNB, Bundesbank, authors’ calculations.

International banks from AT and DE lend to more than 100 recipient countries each directly across borders or via affiliates located abroad. In the analysis of outward spillovers we are going to exploit this notable heterogeneity in the cross-section and time dimension for direct cross-border positions. ${ }^{13}$ To reduce noise, however, we

\footnotetext{
${ }^{13}$ For AT the available unconsolidated data representing direct cross-border positions (used for the estimations in this paper) only cover around $25 \%$ of the consolidated outward positions (which includes foreign subsidiaries' local positions). Unfortunately the detailed split by currency and region on the liability side is not available for the consolidated view. Therefore we focus on cross-border lending.
} 
restrict our outward sample to the most important recipient countries in terms of real sector lending (see section 4.2).

\section{Empirical approach}

In our analyses, the identification of the effect of monetary policy changes on banks' lending stems from the heterogeneity across banks in their reliance on short term funding. We hypothesize that banks that rely more on funding from a certain country or in a certain currency are affected more strongly by changes in the respective monetary policy than other banks and, hence, adjust their lending more. Yet this international bank funding channel of monetary policy might also be subdued in an environment of excess liquidity. Banks that are holding excess central bank reserves are reluctant to lend or might lack lending opportunities but they are presumably not funding constrained. To address this issue econometrically, we apply, in a second step, a triple interaction of the changes in the money market rate, the bank-specific funding variable and the bank-specific liquidity ratio.

\subsection{Inward transmission}

To explore whether foreign monetary policy changes affect domestic lending of resident banks through the bank funding channel, in a first step we estimate the following baseline regression:

(1) $\Delta Y_{b, t}=\alpha_{0}+\sum_{c}\left(\sum_{k=0}^{K}\left(\alpha_{1, k}^{c} \cdot \Delta M P_{t-k}^{c} \cdot F S_{b, t-K-1}^{c}\right)+\alpha_{2, k}^{c} \cdot F S_{b, t-K-1}^{c}\right)+\alpha_{3} X_{b, t-1}+f_{b}+f_{t}+\varepsilon_{b, t}$

The dependent variable $\Delta Y$ is the log change of domestic lending to the private nonfinancial sector. Subscript $b$ denotes banks and $t$ time periods (quarters) while superscript $c$ refers to either countries $\{$ US, UK\} or to currencies $\{$ USD, GBP $\}$ which represent the core financial partners and currencies for Austrian and German banks. Subscript $k$ counts the lags included. To capture one year of monetary policy 
transmission we choose $K=3 . \Delta M P_{t-k}^{c}$ is the change in the monetary policy variable of the respective country measured by the money market rate. ${ }^{14}$

$F S_{b, t-K-1}^{c}$ is the bank-specific funding share measured by gross external liabilities in c relative to total assets. The funding variable enters the regression at the lag $t-K-1$ to ensure that these variables do not reflect the changes in monetary policy.

$X_{b}$ is a vector of the following five bank control variables which might be relevant for the change in lending. Except for the proxy for bank size, all bank characteristics are expressed relative to total assets (see Appendix 1). The log of total assets (bank size) and net intragroup funding reflect potentially preferential access to external funding and ex-ante reliance on internal capital markets. The core deposits ratio captures the extent to which banks access alternative sources of funding outside wholesale funding. The capital ratio accounts for capital constraints that may impair the adjustment of banks' loan supply in response to a monetary policy shock. The liquidity ratio, defined as banks' excess reserves held at the central bank plus cash, approximates the dependence on short-term funding. $f_{t}$ and $f_{b}$ are quarter and bank fixed effects. Standard errors $\epsilon_{b, t}$ are clustered at the bank level.

We are interested in coefficient estimate $\alpha_{1}$. A negative and significant coefficient would provide evidence for inward spillovers of monetary policy changes through an international bank funding channel related to countries or currencies $c$ to Austrian and German debtors.

To examine whether this international monetary policy transmission is hampered in the context of surplus liquidity, in a second step we extend the baseline regression by a triple interaction of the monetary policy variable, the transmission channel and the liquidity ratio.

$$
\begin{aligned}
& \text { (2) } \Delta Y_{b, t}=\alpha_{0}+\sum_{c}\left(\sum _ { k = 0 } ^ { K } \left(\alpha_{1, k}^{c} \Delta M P_{t-k}^{c} \cdot F S_{b, t-K-1}^{c}+\alpha_{2, k}^{c} \Delta M P_{t-k}^{c} \cdot F S_{b, t-K-1}^{c} \cdot L R_{b, t-k}+\alpha_{3, k}^{c} F S_{b, t-K-1}^{c}\right.\right. \\
& \left.\left.\cdot L R_{b, t-k}\right)+\alpha_{4, k} \Delta M P_{t-k}^{c} \cdot L R_{b, t-k}+\alpha_{5, k}^{c} F S_{b, t-K-1}^{c}+\alpha_{6, k} L R_{b, t-k}\right)+\alpha_{7} X_{b, t-1}+f_{b} \\
& +f_{t}+\varepsilon_{b, t}
\end{aligned}
$$

\footnotetext{
${ }^{14}$ The money market rate is our main measure of monetary policy. When discussing the results, we compare the outcomes for the money market rate with estimates obtained using the policy rate or the shadow rate provided by Krippner (2013).
} 
$L R_{b, t-k}$ is the bank-specific liquidity ratio. Banks with high amounts of excess liquidity can assumed to be overfunded and therefore the importance of the bank funding channel for the respective bank might be less apparent. ${ }^{15}$

We are interested in particular in coefficient $\alpha_{2}$ as this shows us the effect of foreign monetary policy changes conditional on the bank-specific endowment with central bank reserves and/or the banks' dependence on the respective foreign funding market. A positive and significant $\alpha_{2}$ would indicate a subdued international bank funding channel the more excess reserves banks hold. Further, we will look at the aggregate effects of $\left(\alpha_{1}+\alpha_{2}\right)^{16}$ to capture the overall impact of monetary policy changes on NFPS lending through the bank funding channel.

\subsection{Outward transmission}

To investigate how euro area monetary policy affects banks' direct cross-border lending, we add the dimension of recipient country $j$ to account for bank-country financial linkages. Subscript $j$ refers to the most important recipient countries outside the euro area. In total for AT 11 and DE 18 recipient countries are included in the analyses. The baseline regression then reads:

(3) $\Delta Y_{b, j, t}=\alpha_{0}+\sum_{k=0}^{K}\left(\alpha_{1, k} \Delta M P_{t-k}^{E A} \cdot F S_{b, j, t-K-1}^{c}+\alpha_{2} F S_{b, j, t-K-1}^{c}\right)+\alpha_{3} X_{b, t-1}+f_{b}+f_{j, t}+\epsilon_{b, j, t}$

The dependent variable $\Delta Y_{b, j, t}$ now is the change in the log cross-border lending of bank $b$ to recipient country $j$ at quarter $t .^{17}$ Superscript $c$ now refers to either the euro area or to the euro. $\Delta M P_{t-k}^{E A}$ are changes in the euro area money market rate. Again we set $K=$ 3 to capture the effect of monetary policy over one year. $F S_{b, j, t-K-1}^{c}$ and $X_{b, t-1}$ are defined as in the inward specification. $f_{j, t}$ are country-quarter fixed effects to control for all other confounding factors, such as demand effects or monetary policy changes in country $j . f_{b}$ are bank fixed effects. Standard errors $\epsilon_{b, j, t}$ are clustered at the bank level.

\footnotetext{
${ }^{15}$ As $L R$ enters the regression as part of the interaction and with four lags, it is no longer part of the vector of control variables $X$.

16 The sum of the two coefficient estimates provides information about the aggregate impact of monetary policy changes conditional on the funding structure (when controlling for the liquidity ratio).

${ }^{17}$ A significant share of external lending is conducted in foreign currencies. However, banks report their outstanding claims in euro. Therefore, we adjust the reported data on outstanding foreign claims for exchange rate changes to obtain information on the mere transaction-induced lending changes.
} 
Again, in a second step, we extend the baseline regression by a triple interaction where $L R_{b, t-k}$ measures the liquidity ratio of bank $b$ :

(4) $\Delta Y_{b, j, t}=\alpha_{0}+\sum_{k=0}^{K}\left(\alpha_{1, k} \Delta M P_{t-k}^{E A} \cdot F S_{b, j, t-K-1}^{c}+\alpha_{2, k} \Delta M P_{t-k}^{E A} \cdot F S_{b, j, t-K-1}^{c} \cdot L R_{b, t-k}+\alpha_{3, k} F S_{b, j, t-K-1}^{c}\right.$

$$
\begin{aligned}
& \left.\cdot L R_{b, t-k}+\alpha_{4, k} \Delta M P_{t-k}^{E A} \cdot L R_{b, t-k}+\alpha_{5} F S_{b, j, t-K-1}^{c}+\alpha_{6, k} L R_{b, t-k}\right)+\alpha_{7} X_{b, t-1}+f_{b} \\
& +f_{j, t}+\epsilon_{b, j, t}
\end{aligned}
$$

Similar to the inward regression exercise, we are interested in the aggregate effect of $\left(\alpha_{1}+\alpha_{2}\right)$ showing the impact of euro area monetary policy changes on cross-border lending to the NFPS in countries outside the euro area through the bank funding channel and the coefficient $\alpha_{2}$ indicating whether surplus liquidity potentially impacts the relevance of the bank funding channel.

\section{Results}

\subsection{Inward transmission}

To compare the country and the currency dimension of banks' funding side for the international transmission of monetary policies, we estimate the above defined regressions with the following bank-specific funding variables $F S_{b}^{c}$ :

- External liabilities from a certain country $\{$ US UK\} to total assets, and

- External liabilities in a certain currency $\{$ USD GBP $\}$ to total assets. ${ }^{18}$

Estimation results for eq. (1) are shown in Table 1; columns (1) and (2) contain results for AT, columns (3) and (4) for DE. In particular we are interested in estimates of the coefficient $\alpha_{1}$ for the interaction term in this regression. As both countries receive a substantial share of funding from abroad and in foreign currency (see Figure 3) we would expect negative coefficient estimates. A tightening (easing) of foreign monetary policies then would be associated with a decrease (increase) in domestic lending that is conditional on the bank-specific share of funding from the respective country or in the respective currency.

\footnotetext{
${ }^{18}$ We focus on total liabilities as this includes liabilities to banks and to private investors alike and therefore represents the most comprehensive measure (see Acharya et al. (2017) and Ivashina et al. (2015)). For robustness, we estimated all the models for liabilities to banks as for our sample the measures are highly and significantly correlated. The results are discussed in section 4.
} 
For Austria we do not find significant estimates for $\alpha_{1}$. For Germany we find a negative and significant coefficient estimate for the interaction of US monetary policy and the funding share in USD (but not for funding rooted in the US) ${ }^{19}$ However, the coefficient estimates are very small (a one percentage point increase in the main policy rate translates into a decrease in lending of about 0.2 percent) and therefore the impact is economically negligible.

We perform a series of robustness checks to examine the sensitivity of our results to small perturbations to all specifications. These robustness tests include alternative measures for monetary policy (i.e. the policy rate and a shadow short rate provided by Krippner 2013), for bank funding (i.e. funding from banks) as well as additional interactions of bank characteristics, the money market rate and the liquidity ratio. ${ }^{20}$ As to specification (1) robustness checks for AT provide weak evidence for inward transmission of US monetary policy as coefficient estimates turn significant with the expected sign when including interactions of the bank-specific controls (not shown in the table) and $\Delta M P_{t-k}^{c}$ as well as when using the main policy rate instead of the money market rate. Robustness checks for DE confirm the above result in all cases.

It is surprising that we find a less stable inward transmission of US monetary policy to Austria, although average foreign funding denominated in USD is higher than in Germany. We have two explanations for this. Firstly, a large part of liabilities in USD stems from Russia (see Figure 5). Assuming that these funds are mainly petrodollars or safe haven investments, the dynamics of these flows of funds are likely to be less driven by short-term monetary policy changes in the US. A second explanation could be a lack of variation over time. The average USD funding share of 6 percent is mainly driven by a small number of banks with funding shares of 40-50 percent while the median funding share is only 2 percent. These shares display relatively little variation over time.

\footnotetext{
${ }^{19}$ As to inward spillovers related to the UK we find some significant coefficients. However, a closer look at the liabilities from the UK or denominated in GBP reveals that their distribution is very uneven across banks (see Appendix 2). The majority of international banks in the German banking system have no funding in GBP at all (the average funding share in GBP is very low with $0.26 \%$, the median is 0 ). In fact, only five percent of all observations show a funding ratio of GBP that is $>1 \%$ and only four banks have more than two percent of their funding denominated in GBP. Hence, while in aggregate funding from the UK or the UK banking sector matters for the German banking system, it seems to be negligible for the majority of banks. Therefore it is unlikely that changes in the price of funding are associated with significant changes in the aggregate credit extension to the private sector. The shares are economically negligible and the statistical significance discovered in our estimations seems to cover other dynamics than those related to funding.

${ }^{20}$ We refer to the results of the robustness checks in order to reinforce our main results. In the paper we only report estimation results for the regressions described in section 3. Other estimation results are available upon request.
} 
Results for Germany indicate that an increase in USD funding costs is associated with a mildly mitigated credit extension the more a bank funds itself in USD (in contrast to funding originating in the US). This result might reflect the fact that only around onethird of German banks' funding in USD actually comes from the US, while a large share comes from offshore countries or financial centres such as the Cayman Islands (KY), the UK, Hong Kong (HK) and elsewhere (see Figure 5). Unlike capital flows linked to the recycling of petrodollars, USD-denominated financial investments are arguably more sensitive to US monetary policy decisions, no matter whether they come from onshore or offshore.

\section{Figure 5: Origin of US dollar funding}

AT

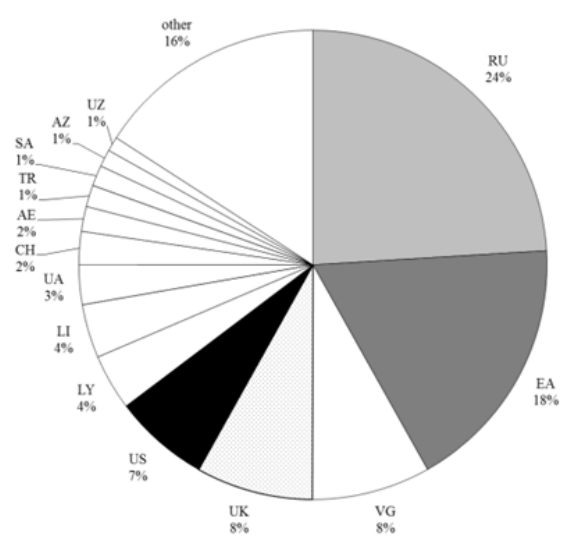

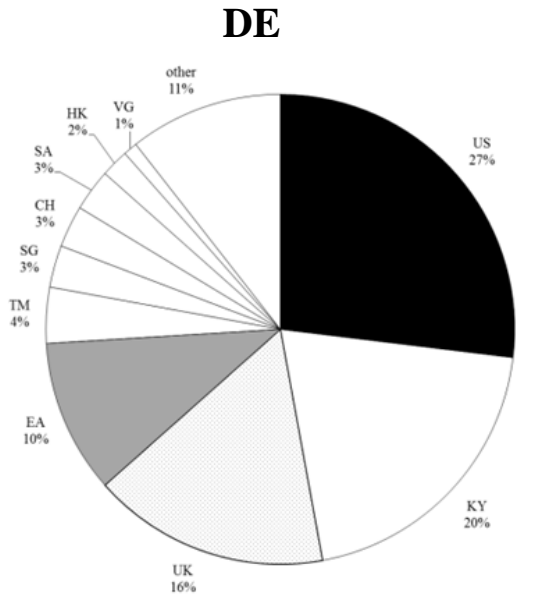

Sources: OeNB, Bundesbank, authors’ calculations.

As discussed above, our sample period 2005-2015 includes periods of unconventional monetary policy in the US, the UK and also the euro area. During these episodes of quantitative easing, international bank funding may be a less important factor for those banks that are less funding constrained due to excess liquidity holdings. To test this hypothesis, we interact the banks' liquidity ratio (defined as cash and central bank reserves to total assets) with the monetary policy changes and the transmission channel variables (see eq. (2)). Estimation results are shown in Table 2. Positive coefficient estimates $\alpha_{2}$ for the triple interaction would provide support to the above hypothesis. The aggregate impact of internationally transmitted foreign monetary policy changes on domestic lending is measured by $\left(\alpha_{1}+\alpha_{2}\right)$ and has to be determined empirically as it is unclear ex ante which effect is dominant.

Generally our results are ambiguous and do not provide a clear picture when considering the liquidity situation of banks (i.e. estimates of $\alpha_{2}$ in Table 2). Those 
estimates and significances presented in Table 2 are not confirmed by robustness checks for either Austria or Germany. As to the transmission of monetary policy (i.e. estimates of $\left.\left(\alpha_{1}+\alpha_{2}\right)\right)$, we find for some of the estimations for Germany statistically significant negative estimates for the funding share in USD. This supports our previous results on the relevance of currency-related channels.

The liquidity endowment does not seem to be a relevant bank characteristic for the international transmission of monetary policy. Generally the liquidity ratio as an indicator of a banks' autonomy from funding markets can vary depending on a bank's business model. In particular, banks that are less engaged in lending to the non-financial private sector might show a higher liquidity ratio during periods of financial stress. Their generally low volumes of real private sector lending might be independent from monetary policy changes and predominantly determined by other factors. Further, other domestic time and bank-specific factors outside of our model and contributing to unobserved heterogeneity in the sample might play a role for domestic lending dynamics. This includes e.g. domestic funding costs and the bank-specific reliance on domestic funding (i.e. rooted in the euro area or denominated in euro).

Generally, as to inward transmission, our results (including all robustness checks) reveal that spillover effects tend to be present when looking at the currency-related channels, although several results are sensitive to changes in the specifications and monetary policy measures. We interpret this as evidence for a superior role of funding currency for the international transmission of monetary policy compared to the country where the funding comes from. The country dimension underestimates the importance of, in particular, US monetary policy for those banks that depend on US dollar funding as substantial parts of this funding originate in third countries. The currency dimension seems to capture this much better. The limited evidence for inward transmission is also due to the given low shares of foreign funding for the majority of banks in the Austrian and German banking system. In the event of changing funding patterns in the future, however, inward transmission may reach economically significant magnitude.

\subsection{Outward transmission}

The largest funding share of Austria's and Germany's banks is rooted in the euro area and denominated in euro. At the same time several banks are international creditors. Therefore, the international bank funding channel might be more pronounced in the outward transmission of domestic monetary policy. To test this, we analyse whether euro area monetary policy changes affect cross-border lending of those banks. Similar 
to the inward regressions, we examine the implications of bank heterogeneity regarding the following funding share variables $F S_{b}^{c}$ :

- Liabilities from the euro area to total assets, and

- Liabilities in EUR to total assets.

Estimation results for the baseline outward regression (see eq. (3)) are shown in Table 3. As funding from the euro area as well as in euro represent a notable share for banks in both countries and as both banking systems have sizable cross-border exposures, we would expect a tightening (easing) of monetary policy in the euro area to be followed by a decrease (increase) in cross-border credit extension, i.e. positive coefficient estimates for $\alpha_{1}$ in eq. (3) and for $\left(\alpha_{1}+\alpha_{2}\right)$ in eq. (4). ${ }^{21}$

Surprisingly we find no robust significant impact of euro area monetary policy changes on banks' external lending contingent on the aforementioned funding characteristics neither for Austria nor for Germany (see Tables 3 and 4). In our robustness checks we only find weak evidence for outward spillovers through DE banks when looking at funding from banks and when looking at funding in EUR and the main policy rate as well as the shadow short rate as our monetary policy measure. However, as results are not robust to different regression specifications and significant coefficients are generally small, we do not interpret these findings as strong evidence in favour of outward spillovers.

Despite the lack of evidence for an impact of euro area monetary policy changes on cross-border lending to the non-financial private sector outside the euro area, we cannot infer from our results that domestic monetary policy is not transmitted through local lending of subsidiaries located abroad. For instance, the data used for the AT estimations only cover approximately 25 percent of consolidated foreign lending. The remaining 75 percent of foreign lending is extended by subsidiaries located outside of Austria. For our analyses we cannot use the database for Austrian subsidiaries as it does not provide a detailed split by currency and country on the liability side.

Further, as in particular banks from Austria have a significant footprint in Eastern European economies, we explore whether the lending behaviour towards these countries is different. When restricting the sample to non-euro area but EU countries (only five

\footnotetext{
${ }^{21}$ We restrict the sample to bank-country combinations where the share of cross-border lending to the country has a minimum share of 1 percent in total cross-border lending on average over the sample period. This restriction reduces the sample significantly. The full sample is more than 14,000 observations, 28 banks and 63 countries for AT and more than 35,000 observations, 72 banks and 55 countries for DE. However, the remaining sample includes 53 percent of total cross border loans in AT and 77 percent in DE over the whole sample period. Using the full sample or reducing the restriction to 0.5 percent does not qualitatively change the estimation results.
} 
(AT) and eight (DE) economies remain in the sample for the estimation) we find that a tightening (easing) of euro area monetary policy is associated with more (less) crossborder lending to those countries from AT banks (but not from DE banks). ${ }^{22}$ It might be that the portfolio channel works here as a tightening of monetary policy in the euro area makes domestic (i.e. euro area) borrowers relatively more risky and banks therefore shift parts of their business abroad, in particular to those countries where they have established strong creditor-debtor relationships and a substantial market share. In contrast, for DE results tend to go in the same direction as in the baseline estimation from eq. (3). The coefficient on funding from banks is negative and significant but hinges on the choice of the monetary policy measure.

\section{Conclusion}

Our paper explores the role of bank funding in the international transmission of monetary policy. In a first step, we compare the geographic and currency dimensions of bank funding for the banking systems of Austria and Germany using confidential bank balance sheet data. By breaking down banks' funding according to the country where it comes from as well as according to the currency it is denominated in, we observe that the two dimensions differ substantially. While for both banking systems the majority of funding is denominated in euro and originates within the euro area, the most relevant foreign currency is the US dollar, but the most relevant foreign country is the UK, with London being the European banking hub.

In a second step, we explore the role of international bank funding by analysing how banks' funding, disaggregated by country or by currency, impacts the international transmission of monetary policy to bank lending. We distinguish between inward transmission (of foreign monetary policy to domestic lending) and outward transmission (of euro area monetary policy to domestic banks' cross-border lending). By controlling for the liquidity position of individual banks vis-à-vis the central bank, we further explore the role of the heterogeneity in the degree of funding necessities, i.e. of the role of conventional and unconventional monetary policy.

Our results provide weak evidence for the international transmission of monetary policy through banks' funding structure to credit extension by banks in AT and DE. The monetary policy of the US, home of the major foreign funding currency, seems to affect the supply of credit to the domestic non-financial private sector the more a bank funds

\footnotetext{
${ }^{22}$ Estimation results are available upon request.
} 
its operations in US dollars. This effect is more pronounced in Germany than in Austria. However, these spillovers are statistically significant but not large economically. As the major country and currency for funding of the Austrian and the German banking system are, respectively, the euro area and the euro, this result is of little surprise. As for outward transmission, we do not find evidence for an impact of monetary policy changes in the euro area on direct cross-border lending.

Generally, our estimation results are not very robust to changes in the specifications and alternative monetary policy measures. Therefore we are reluctant to argue in favour of bank funding structures being a major transmission channel for international spillovers of monetary policy. Other particular characteristics of banks are likely to be associated with a higher responsiveness to monetary policy changes. However, our work shows that it does make a difference whether positions that are deemed to act as international transmission channels of monetary policy are defined by country or by currency. 
Table 1: Inward regression results - baseline

\begin{tabular}{|c|c|c|c|c|}
\hline \multirow[b]{2}{*}{ Dimension: } & \multicolumn{2}{|c|}{ AT } & \multicolumn{2}{|c|}{ DE } \\
\hline & $\begin{array}{c}\text { (1) } \\
\text { by country }\end{array}$ & $\begin{array}{c}\text { (2) } \\
\text { by currency }\end{array}$ & $\begin{array}{c}\text { (3) } \\
\text { by country }\end{array}$ & $\begin{array}{c}\text { (4) } \\
\text { by currency }\end{array}$ \\
\hline \multirow[t]{2}{*}{ US: $\Sigma \alpha_{1, \mathrm{k}} * \mathrm{MP}_{\mathrm{k}} * \mathrm{FS}(\mathrm{t}-4)$} & 0.233 & -0.006 & 0.9476 & $-0.223 *$ \\
\hline & {$[0.659]$} & {$[0.939]$} & {$[0.152]$} & {$[0.072]$} \\
\hline \multirow{2}{*}{ UK: $\Sigma \alpha_{1, \mathrm{k}} * \mathrm{MP}_{\mathrm{k}} * \mathrm{FS}(\mathrm{t}-4)$} & 0.458 & 0.487 & 0.000 & 0.884 \\
\hline & {$[0.254]$} & {$[0.748]$} & {$[0.978]$} & {$[0.212]$} \\
\hline \multirow[t]{2}{*}{ US: $\alpha_{2} * F S(t-4)$} & 0.304 & $-0.488^{*}$ & 0.131 & $0.282 * *$ \\
\hline & {$[0.261]$} & {$[0.084]$} & {$[0.399]$} & {$[0.027]$} \\
\hline \multirow[t]{2}{*}{ UK: $\alpha_{2} *$ FS (t-4) } & $0.422 * *$ & $0.418^{* * *}$ & 0.015 & 0.525 \\
\hline & {$[0.008]$} & {$[0.000]$} & {$[0.804]$} & {$[0.606]$} \\
\hline \multirow[t]{2}{*}{$\alpha_{3} *$ Liquidity ratio (t- 1 ) } & 0.326 & 0.320 & -0.239 & -0.239 \\
\hline & {$[0.322]$} & {$[0.259]$} & {$[0.175]$} & {$[0.179]$} \\
\hline \multirow[t]{2}{*}{$\alpha_{3} *$ Log of total assets $(t-1)$} & -0.014 & $-0.059 * *$ & -1.474 & -1.472 \\
\hline & {$[0.477]$} & {$[0.036]$} & {$[0.155]$} & {$[0.132]$} \\
\hline \multirow[t]{2}{*}{$\alpha_{3} *$ Capital ratio $(\mathrm{t}-1)$} & $-0.280 * *$ & $-0.485^{* *}$ & 0.077 & 0.189 \\
\hline & {$[0.035]$} & {$[0.012]$} & {$[0.589]$} & {$[0.150]$} \\
\hline \multirow[t]{2}{*}{$\alpha_{3} *$ Net intra-bank funding ratio (t-1) } & 0.052 & 0.316 & 0.030 & -0.045 \\
\hline & [0.767] & [0.246] & [0.679] & [0.429] \\
\hline \multirow[t]{2}{*}{$\alpha_{3} *$ Deposit ratio $(t-1)$} & -0.085 & -0.039 & $0.068^{* *}$ & $0.060 * *$ \\
\hline & {$[0.251]$} & {$[0.538]$} & {$[0.013]$} & {$[0.016]$} \\
\hline $\mathrm{R}^{2}$ & 0.073 & 0.118 & 0.064 & 0.090 \\
\hline Adjusted $\mathrm{R}^{2}$ & 0.025 & 0.072 & 0.047 & 0.074 \\
\hline Observations & 1074 & 1074 & 3041 & 3041 \\
\hline Number of banks & 28 & 28 & 78 & 78 \\
\hline Quarter fixed effects & yes & yes & yes & yes \\
\hline Bank fixed effects & yes & yes & yes & yes \\
\hline $\begin{array}{l}\text { Notes: This table shows estimation results fo } \\
\text { lending to the domestic non-financial private } \\
\text { policy, FS refers to the share of gross external } \\
\text { refers to the number of lags and goes from } 0 \mathrm{t} \\
\text { are in bold. Robust } \mathrm{p} \text {-values are presented in } \\
\text { clustered by bank. }{ }^{* * *},{ }^{* *} \text {, and }{ }^{*} \text { denote statis } \\
\text { Sources: OeNB, Bundesbank, authors' calcula }\end{array}$ & $\begin{array}{l}\text { equation (1). Th } \\
\text { ector. MP refer } \\
\text { unding (by coun } \\
\text { 3. Those variak } \\
\text { arentheses bel } \\
\text { ical significance } \\
\text { ons. }\end{array}$ & $\begin{array}{l}\text { lependent varia } \\
\text { the money ma } \\
\text { or by currency } \\
\text { that are of par } \\
\text { the coefficient } \\
\text { the } 1,5 \text { and } 10\end{array}$ & $\begin{array}{l}\text { he first differe } \\
\text { te as a measur } \\
\text { ion) in total as } \\
\text { interest for ou } \\
\text { tes. Standard } \\
\text { ht level. }\end{array}$ & $\begin{array}{l}\text { of the log of } \\
\text { f monetary } \\
\text { s. Subscript k } \\
\text { search question } \\
\text { ors are }\end{array}$ \\
\hline
\end{tabular}


Table 2: Inward regression results including the liquidity ratio interaction

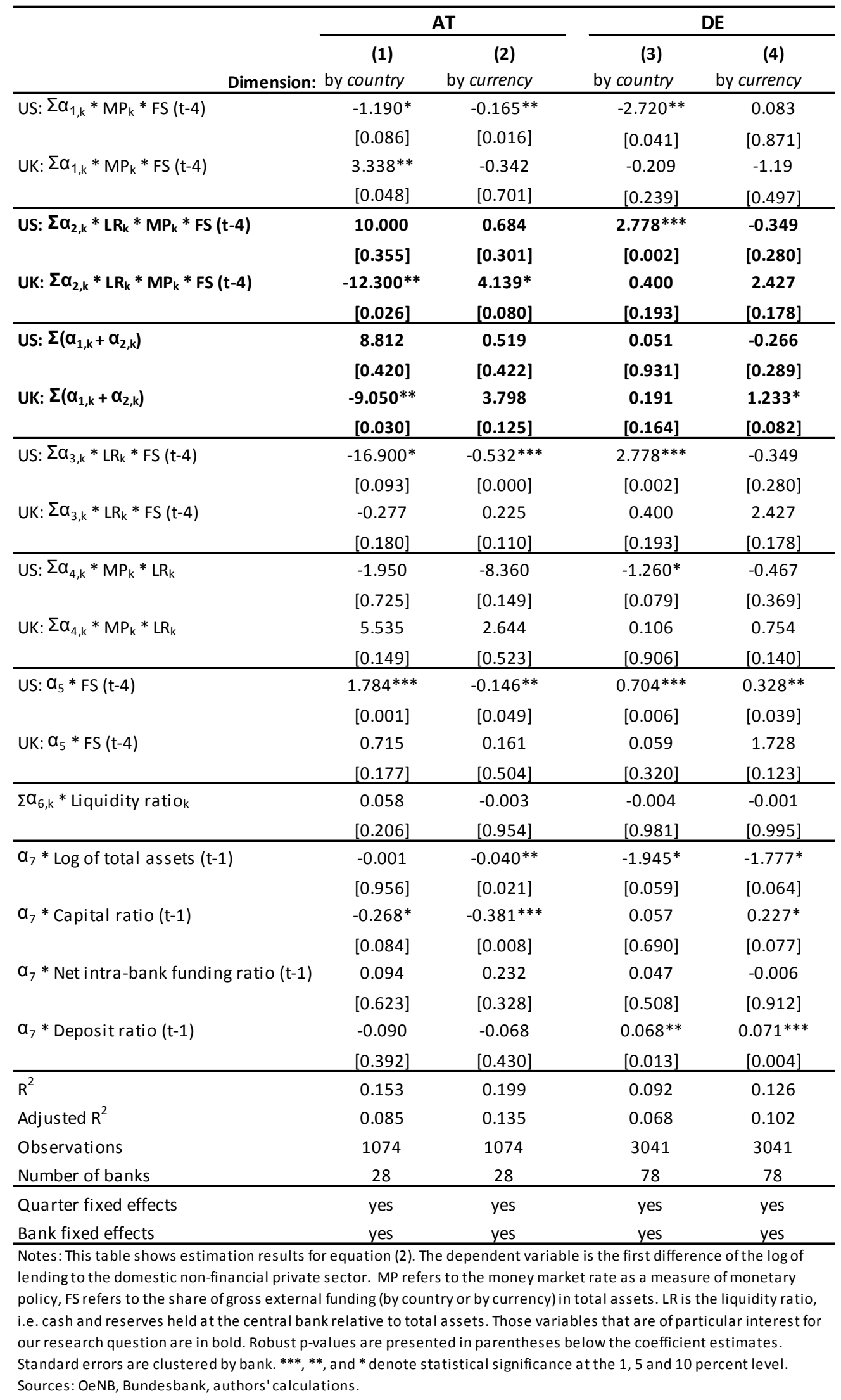


Table 3: Outward regression results - baseline

\begin{tabular}{|c|c|c|c|c|}
\hline \multirow[b]{2}{*}{ Dimension: } & \multicolumn{2}{|c|}{ AT } & \multicolumn{2}{|c|}{$\mathrm{DE}$} \\
\hline & $\begin{array}{c}\text { (1) } \\
\text { by country }\end{array}$ & $\begin{array}{c}\text { (2) } \\
\text { by currency }\end{array}$ & $\begin{array}{c}\text { (3) } \\
\text { by country }\end{array}$ & $\begin{array}{c}\text { (4) } \\
\text { by currency }\end{array}$ \\
\hline \multirow[t]{2}{*}{$\Sigma \alpha_{1, \mathrm{k}} * M P_{\mathrm{k}} * \mathrm{FS}(\mathrm{t}-4)$} & -0.043 & -0.016 & -0.048 & 0.051 \\
\hline & {$[0.737]$} & {$[0.822]$} & {$[0.436]$} & {$[0.605]$} \\
\hline \multirow[t]{2}{*}{$\alpha_{2} * \mathrm{FS}(\mathrm{t}-4)$} & $0.187^{* *}$ & 0.104 & -0.082 & -0.120 \\
\hline & {$[0.039]$} & [0.109] & [0.292] & {$[0.134]$} \\
\hline \multirow[t]{2}{*}{$\alpha_{3} *$ Liquidity ratio (t-1) } & 0.460 & 0.901 & -0.268 & -0.285 \\
\hline & {$[0.576]$} & {$[0.305]$} & {$[0.540]$} & {$[0.497]$} \\
\hline \multirow[t]{2}{*}{$\alpha_{3} *$ Log of total assets $(t-1)$} & -0.013 & -0.020 & $4.111^{*}$ & 3.875 \\
\hline & [0.592] & [0.389] & [0.095] & [0.107] \\
\hline \multirow[t]{2}{*}{$\alpha_{3} *$ Capital ratio $(t-1)$} & 0.025 & 0.016 & $0.548^{*}$ & $0.550 *$ \\
\hline & [0.912] & [0.942] & {$[0.053]$} & {$[0.056]$} \\
\hline \multirow[t]{2}{*}{$\alpha_{3} *$ Net intra-bank funding ratio (t-1) } & $0.856 *$ & $0.870 *$ & -0.003 & -0.001 \\
\hline & {$[0.090]$} & {$[0.088]$} & [0.985] & [0.997] \\
\hline \multirow[t]{2}{*}{$\alpha_{3} *$ Deposit ratio $(t-1)$} & 0.301 & 0.229 & -0.016 & -0.063 \\
\hline & {$[0.131]$} & [0.183] & {$[0.930]$} & {$[0.660]$} \\
\hline $\mathrm{R}^{2}$ & 0.476 & 0.476 & 0.374 & 0.374 \\
\hline Adjusted $\mathrm{R}^{2}$ & 0.187 & 0.187 & 0.137 & 0.136 \\
\hline Observations & 1269 & 1269 & 2,733 & 2,733 \\
\hline Number of banks & 22 & 22 & 31 & 31 \\
\hline Number of countries & 11 & 11 & 18 & 18 \\
\hline Country-quarter fixed effects & yes & yes & yes & yes \\
\hline Bank fixed effects & yes & yes & yes & yes \\
\hline
\end{tabular}

Notes: This table shows estimation results for equation (3). The dependent variable is the first difference of the log of direct cross-border lending to the non-financial private sector. MP refers to the money market rate as a measure of monetary policy in the euro area, FS refers to the share of gross external funding (by country or by currency dimension) in total assets. Subscript $k$ refers to the number of lags and goes from 0 to 3 . Those variables that are of particular interest for our research question are in bold. Robust $p$-values are presented in parentheses below the coefficient estimates. Standard errors are clustered by bank. ${ }^{* * *}, * *$, and $*$ denote statistical significance at the 1,5 and 10 percent level. Sources: OeNB, Bundesbank, authors' calculations. 
Table 4: Outward regression results including the liquidity ratio interaction

\begin{tabular}{|c|c|c|c|c|}
\hline \multirow[b]{2}{*}{ Dimension: } & \multicolumn{2}{|c|}{ AT } & \multicolumn{2}{|c|}{$\mathrm{DE}$} \\
\hline & $\begin{array}{c}\text { (1) } \\
\text { by country }\end{array}$ & $\begin{array}{c}\text { (2) } \\
\text { by currency }\end{array}$ & $\begin{array}{c}\text { (3) } \\
\text { by country }\end{array}$ & $\begin{array}{c}\text { (4) } \\
\text { by currency }\end{array}$ \\
\hline \multirow[t]{2}{*}{$\sum \alpha_{1, \mathrm{k}} * \mathrm{MP}_{\mathrm{k}} * \mathrm{FS}(\mathrm{t}-4)$} & 0.014 & 0.001 & -0.190 & 0.094 \\
\hline & {$[0.937]$} & {$[0.992]$} & {$[0.124]$} & {$[0.401]$} \\
\hline \multirow[t]{2}{*}{$\Sigma \alpha_{2, \mathrm{k}} * M P_{\mathrm{k}} * \mathrm{FS}(\mathrm{t}-4) * \mathrm{LR}_{\mathrm{k}}$} & -0.093 & 0.002 & 0.133 & -0.073 \\
\hline & {$[0.868]$} & {$[0.996]$} & {$[0.313]$} & {$[0.624]$} \\
\hline \multirow[t]{2}{*}{$\Sigma\left(\alpha_{1, k}+\alpha_{2, k}\right)$} & -0.081 & 0.003 & -0.057 & 0.020 \\
\hline & {$[0.869]$} & [0.992] & {$[0.449]$} & {$[0.985]$} \\
\hline \multirow[t]{2}{*}{$\Sigma \alpha_{3, k} * F S(t-4) * L R_{k}$} & 0.366 & 0.178 & 0.043 & 0.001 \\
\hline & [0.257] & {$[0.146]$} & [0.182] & {$[0.401]$} \\
\hline \multirow[t]{2}{*}{$\Sigma \alpha_{4, \mathrm{k}} * \mathrm{MP}_{\mathrm{k}} * \mathrm{LR}_{\mathrm{k}}$} & -0.004 & -0.065 & -4.909 & 5.699 \\
\hline & {$[0.989]$} & {$[0.880]$} & {$[0.429]$} & {$[0.846]$} \\
\hline \multirow[t]{2}{*}{$\alpha_{5}$ FS (t-4) } & 0.102 & 0.046 & $-0.145^{*}$ & -0.122 \\
\hline & [0.282] & [0.503] & [0.068] & [0.189] \\
\hline \multirow[t]{2}{*}{$\alpha_{6, \mathrm{k}} *$ Liquidity ratio $o_{\mathrm{k}}$} & -0.293 & $-0.275^{*}$ & -2.062 & 0.012 \\
\hline & [0.168] & {$[0.083]$} & [0.429] & [0.569] \\
\hline \multirow[t]{2}{*}{$\alpha_{7} * \log$ of total assets (t- 1$)$} & 0.009 & -0.004 & 3.202 & 3.918 \\
\hline & {$[0.788]$} & [0.893] & {$[0.146]$} & {$[0.138]$} \\
\hline \multirow[t]{2}{*}{$\alpha_{7} *$ Capital ratio $(t-1)$} & -0.110 & -0.085 & 0.486 & $0.578 * *$ \\
\hline & {$[0.700]$} & {$[0.751]$} & {$[0.108]$} & {$[0.046]$} \\
\hline \multirow[t]{2}{*}{$\alpha_{7} *$ Net intra-bank funding ratio (t-1) } & $0.893^{*}$ & 0.862 & -0.018 & -0.006 \\
\hline & [0.092] & [0.108] & {$[0.897]$} & [0.968] \\
\hline \multirow[t]{2}{*}{$\alpha_{7} *$ Deposit ratio $(t-1)$} & $0.319 *$ & 0.234 & 0.028 & -0.059 \\
\hline & {$[0.100]$} & [0.148] & {$[0.874]$} & [0.690] \\
\hline $\mathrm{R}^{2}$ & 0.505 & 0.504 & 0.383 & 0.379 \\
\hline Adjusted $\mathrm{R}^{2}$ & 0.219 & 0.218 & 0.142 & 0.136 \\
\hline Observations & 1269 & 1269 & 2733 & 2733 \\
\hline Number of banks & 22 & 22 & 31 & 31 \\
\hline Number of countries & 11 & 11 & 18 & 18 \\
\hline Country-quarter fixed effects & yes & yes & yes & yes \\
\hline Bank fixed effects & yes & yes & yes & yes \\
\hline
\end{tabular}

Notes: This table shows estimation results for equation (4). The dependent variable is the first difference of the log of direct cross-border lending to the non-financial private sector. MP refers to the money market rate as a measure of monetary policy in the euro area, FS refers to the share of gross external funding (by country or by currency dimension) in total assets. Subscript $k$ refers to the number of lags and goes from 0 to 3 . Those variables that are of particular interest for our research question are in bold. Robust $p$-values are presented in parentheses below the coefficient estimates. Standard errors are clustered by bank. ${ }^{* *}, * *$, and ${ }^{*}$ denote statistical significance at the 1,5 and 10 percent level. Sources: OeNB, Bundesbank, authors' calculations. 


\section{References}

Acharya, V., D. Pierret, and S. Steffen (2017), Lender of last resort versus buyer of last resort - evidence from the European sovereign debt crisis, available from: https://papers.ssrn.com/sol3/papers.cfm?abstract_id=2762265.

Avdjiev, S. and E. Takáts (2016), Monetary policy spillovers and currency networks in cross-border bank lending, BIS Working Papers No. 549.

Braeuning, F., and V. Ivashina (2017), Monetary policy and global banking, NBER Working Paper No. 23316.

Bruno, V. and H.-S. Shin (2015), Capital flows and the risk-taking channel of monetary policy, Journal of Monetary Economics, Vol. 71, p. 119-132.

Cetorelli, N. and L. Goldberg (2012), Banking globalization and monetary transmission, Journal of Finance, Vol. 67, p. 1811-1843.

Chen, Q., A. Filardo, D. He, and F. Zhu (2016), Financial crisis, US unconventional monetary policy and international spillovers, Journal of International Money and Finance, Vol. 67, p. 62-81.

Correa, R., and C. Murry (2010), Is there a cross-border bank lending channel? Evidence from US banks’ international exposure, CGFS Papers No 40, p. 113-132.

De Haas, R., Y. Korniyenko, A. Pivovarsky, and T. Tsankova (2015), Taming the herd? Foreign banks, the Vienna Initiative and crisis transmission, Journal of Financial Intermediation, Vol.24 (3), p.325-55.

Ehrmann, M., L. Gambacorta, J. Martinez Pagés, P. Sevestre and A. Worms (2003), Financial systems and the role of banks in monetary policy transmission in the euro area, in Angeloni, I., A. Kashyap, B. Mojon (eds.), Monetary Policy Transmission in the Euro Area, Cambridge University Press, p. 235-269.

Fratzscher, M., M. Lo Duca and R. Straub (2016), ECB unconventional monetary policy: Market impact and international spillovers, IMF Economic Review, Vol. 64, p. 36-74.

Frey, R. and C. Kerl (2015), Multinational banks in the crisis: Foreign affiliate lending as a mirror of funding pressure and competition on the internal capital market, Journal of Banking and Finance, Vol. 50, p. 52-68.

Gambacorta, L. and H.-S. Shin (2016), Why bank capital matters for monetary policy, BIS Working Paper No. 558. 
Gambacorta, L. and P. Mistrulli (2004), Does bank capital affect lending behaviour?, Journal of Financial Intermediation, Vol. 13(4), p. 436-457.

Hale, G., T. Kapan, and C. Minoiu (2016), Crisis transmission through the global banking network, IMF Working Paper WP/16/91.

Hofmann, B. and E. Takáts (2015), International monetary spillovers, BIS Quarterly Review, p. 105-118.

Ivashina, V., D. Scharfstein, and J. Stein (2015) Dollar funding and the lending behaviour of global banks, Quarterly Journal of Economics, p. 1241-1281.

Krippner, L. (2013) Measuring the stance of monetary policy in zero lower bound environments, Economics Letters, Vol. 118(1), p. 135-138.

Morais, B., J.-L. Peydró, and C. Ruiz (2018) The international bank lending channel of monetary policy rates and QE: Credit supply, reach-for-yield, and real effects, Journal of Finance, forthcoming.

Puri, M., J. Rocholl, and S. Steffen (2011) Global retail lending in the aftermath of the US financial crisis: Distinguishing between supply and demand effects, Journal of Financial Economics, Vol. 100(3), p. 556-578. 


\section{Appendix}

\section{Appendix 1: Variable definitions}

\section{Control variables}

\begin{tabular}{ll} 
Variable & Definition \\
\hline Log total assets & log of total assets (in EUR) \\
\hline Capital ratio & total capital / total assets \\
\hline Net intra-group funding ratio & $\begin{array}{l}\text { net claims of foreign branches abroad vis-à-vis the domestic banking system } \\
\text { (excl. central bank) / total assets of the domestic parent }\end{array}$ \\
\hline & $\begin{array}{l}\text { (deposits by non-banks (of all maturities) - deposits by non-bank financial } \\
\text { intermediaries - repos)/ total liabilities } \\
\text { Deposits ratio }\end{array}$ \\
& or \\
\hline Liquidity ratio & (cavings deposits + sight deposits of the non-financial sector) / total assets \\
\hline
\end{tabular}

\section{Funding Share variables}

Inward transmission

External liabilities ratio

gross liabilities to a country \{US UK\} or denominated in a certain currency \{USD GBP / total assets

External liabilities to banks ratio

gross external liabilities to banks in a country $\{$ US UK\} or denominated in a certain currency $\{$ USD GBP $\}$ / total assets

Outward transmission

Liabilities ratio

gross liabilities to the euro area or denominated in EUR / total assets

Liabilities to banks ratio gross liabilities to banks in the euro area or denominated in EUR / total assets 


\section{Appendix 2: Summary statistics}

\begin{tabular}{|c|c|c|c|c|c|}
\hline & & \multicolumn{2}{|c|}{ AT } & \multicolumn{2}{|c|}{ DE } \\
\hline & & mean & sd & mean & sd \\
\hline \multicolumn{6}{|l|}{ General characteristics and statistics } \\
\hline \multicolumn{2}{|c|}{ Total assets of the resident banking sector incl. in the study (EUR mn) } & 344,341 & 39,775 & $5,660,000$ & 374,000 \\
\hline \multicolumn{2}{|c|}{ Number of banks } & 27.54 & 0.76 & 76.27 & 1.15 \\
\hline \multicolumn{2}{|l|}{ Total bank assets (EUR mn) } & 19,503 & 32,660 & 74,705 & 210,010 \\
\hline \multicolumn{2}{|c|}{ Domestic lending (EUR mn) } & 8,881 & 13,396 & 26,088 & 44,056 \\
\hline \multicolumn{2}{|c|}{ Loans to the domestic non-financial private sector (EUR mn) } & 4,376 & 7,963 & 12,096 & 19,234 \\
\hline \multicolumn{2}{|c|}{ Log changes in loans to the domestic non-fin. private sector *100 } & 0.17 & 11.39 & 0.19 & 9.01 \\
\hline \multicolumn{2}{|c|}{ Log changes in loans to the domestic banking sector ${ }^{*} 100$} & -2.35 & 65.26 & -0.81 & 30.21 \\
\hline \multicolumn{2}{|c|}{ Log changes in cross-border loans to the NFPS in non-EA countries *100 } & 0.79 & 13.22 & 0.13 & 19.70 \\
\hline \multicolumn{2}{|c|}{ Log changes in cross-border loans to banks in non-EA countries $* 100$} & 14.51 & 1.75 & 0.11 & 33.96 \\
\hline \multicolumn{6}{|c|}{ Balance sheet controls (ratios in \%) } \\
\hline \multicolumn{2}{|l|}{ Log total assets } & 15.60 & 1.62 & 23.31 & 1.98 \\
\hline \multicolumn{2}{|l|}{ Capital ratio } & 8.63 & 3.92 & 4.87 & 3.13 \\
\hline \multicolumn{2}{|l|}{ Liquidy ratio } & 0.38 & 0.95 & 1.16 & 1.68 \\
\hline \multicolumn{2}{|l|}{ Net intra-group funding ratio } & -0.02 & 3.91 & -1.43 & 5.09 \\
\hline \multicolumn{2}{|l|}{ Core deposits ratio } & 31.07 & 19.81 & 25.14 & 25.10 \\
\hline \multirow{2}{*}{\multicolumn{2}{|c|}{$\begin{array}{l}\text { Funding share variables (\% of total assets) } \\
\text { Inward dimension: }\end{array}$}} & \multicolumn{2}{|c|}{ AT } & \multicolumn{2}{|c|}{ DE } \\
\hline & & mean & $\mathrm{sd}$ & mean & $s d$ \\
\hline External liabilities & country: US & 0.51 & 2.06 & 0.38 & 1.40 \\
\hline External liabilities & currency: USD & 5.99 & 9.91 & 2.24 & 5.59 \\
\hline External liabilities & country: UK & 1.27 & 4.46 & 3.23 & 12.11 \\
\hline External liabilities & currency: GBP & 0.86 & 4.35 & 0.26 & 0.85 \\
\hline External liabilities to banks & country: US & 0.09 & 0.26 & 0.40 & 1.56 \\
\hline External liabilities to banks & currency: USD & 1.98 & 3.08 & 2.04 & 5.03 \\
\hline External liabilities to banks & country: UK & 0.37 & 0.72 & 2.84 & 11.84 \\
\hline \multirow[t]{2}{*}{ External liabilities to banks } & currency: GBP & 0.13 & 0.34 & 0.26 & 0.85 \\
\hline & & \multicolumn{2}{|c|}{ AT } & \multicolumn{2}{|c|}{$\mathrm{DE}$} \\
\hline \multicolumn{2}{|l|}{ Outward dimension: } & mean & $\mathrm{sd}$ & mean & $\mathrm{sd}$ \\
\hline Liabilities from the euro area & country: EA & 51.72 & 21.01 & 38.93 & 21.43 \\
\hline Liabilities denominated in euro & currency: EUR & 96.08 & 37.93 & 61.34 & 16.29 \\
\hline Liabilities to banks in the euro area & country: EA & 22.07 & 17.15 & 11.48 & 10.57 \\
\hline Liabilities to banks denominated in euro & currency: EUR & 38.04 & 32.62 & 29.25 & 20.32 \\
\hline
\end{tabular}




\section{Index of Working Papers:}

\begin{tabular}{|c|c|c|c|}
\hline $\begin{array}{l}\text { March 5, } \\
2015\end{array}$ & $\begin{array}{l}\text { Jonas Dovern, } \\
\text { Martin Feldkircher, } \\
\text { Florian Huber }\end{array}$ & 200 & $\begin{array}{l}\text { Does Joint Modelling of the World Economy } \\
\text { Pay Off? Evaluating Global Forecasts from a } \\
\text { Bayesian GVAR }\end{array}$ \\
\hline $\begin{array}{l}\text { May 19, } \\
2015\end{array}$ & Markus Knell & 201 & $\begin{array}{l}\text { The Return on Social Security with } \\
\text { Increasing Longevity }\end{array}$ \\
\hline $\begin{array}{l}\text { June 15, } \\
2015\end{array}$ & Anil Ari & 202 & Sovereign Risk and Bank Risk-Taking \\
\hline $\begin{array}{l}\text { June 15, } \\
2015\end{array}$ & Matteo Crosignani & 203 & $\begin{array}{l}\text { Why Are Banks Not Recapitalized During } \\
\text { Crises? }\end{array}$ \\
\hline $\begin{array}{l}\text { February 19, } \\
2016\end{array}$ & Burkhard Raunig & 204 & Background Indicators \\
\hline $\begin{array}{l}\text { February 22, } \\
2016\end{array}$ & $\begin{array}{l}\text { Jesús Crespo } \\
\text { Cuaresma, } \\
\text { Gernot Doppelhofer, } \\
\text { Martin Feldkircher, } \\
\text { Florian Huber }\end{array}$ & 205 & US Monetary Policy in a Globalized World \\
\hline $\begin{array}{l}\text { March 4, } \\
2016\end{array}$ & $\begin{array}{l}\text { Helmut Elsinger, } \\
\text { Philipp Schmidt- } \\
\text { Dengler, } \\
\text { Christine Zulehner }\end{array}$ & 206 & Competition in Treasury Auctions \\
\hline $\begin{array}{l}\text { May 14, } \\
2016\end{array}$ & $\begin{array}{l}\text { Apostolos } \\
\text { Thomadakis }\end{array}$ & 207 & $\begin{array}{l}\text { Determinants of Credit Constrained Firms: } \\
\text { Evidence from Central and Eastern Europe } \\
\text { Region }\end{array}$ \\
\hline $\begin{array}{l}\text { July 1, } \\
2016\end{array}$ & $\begin{array}{l}\text { Martin Feldkircher, } \\
\text { Florian Huber }\end{array}$ & 208 & $\begin{array}{l}\text { Unconventional US Monetary Policy: New } \\
\text { Tools Same Channels? }\end{array}$ \\
\hline $\begin{array}{l}\text { November 24, } \\
2016\end{array}$ & François de Soyres & 209 & $\begin{array}{l}\text { Value Added and Productivity Linkages } \\
\text { Across Countries }\end{array}$ \\
\hline $\begin{array}{l}\text { November 25, } \\
2016\end{array}$ & Maria Coelho & 210 & $\begin{array}{l}\text { Fiscal Stimulus in a Monetary Union: } \\
\text { Evidence from Eurozone Regions }\end{array}$ \\
\hline $\begin{array}{l}\text { January 9, } \\
2017\end{array}$ & $\begin{array}{l}\text { Markus Knell, } \\
\text { Helmut Stix }\end{array}$ & 211 & Inequality, Perception Biases and Trust \\
\hline
\end{tabular}




\begin{tabular}{|c|c|c|c|}
\hline $\begin{array}{l}\text { January 31, } \\
2017\end{array}$ & $\begin{array}{l}\text { Steve Ambler, } \\
\text { Fabio Rumler }\end{array}$ & 212 & $\begin{array}{l}\text { The Effectiveness of Unconventional } \\
\text { Monetary Policy Announcements in the Euro } \\
\text { Area: An Event and Econometric Study }\end{array}$ \\
\hline $\begin{array}{l}\text { May 29, } \\
2017\end{array}$ & Filippo De Marco & 213 & $\begin{array}{l}\text { Bank Lending and the European Sovereign } \\
\text { Debt Crisis }\end{array}$ \\
\hline $\begin{array}{l}\text { June 1, } \\
2017\end{array}$ & Jean-Marie Meier & 214 & $\begin{array}{l}\text { Regulatory Integration of International } \\
\text { Capital Markets }\end{array}$ \\
\hline $\begin{array}{l}\text { October 13, } \\
2017\end{array}$ & Markus Knell & 215 & Actuarial Deductions for Early Retirement \\
\hline $\begin{array}{l}\text { October 16, } \\
2017\end{array}$ & $\begin{array}{l}\text { Markus Knell, } \\
\text { Helmut Stix }\end{array}$ & 216 & Perceptions of Inequality \\
\hline $\begin{array}{l}\text { November 17, } \\
2017\end{array}$ & $\begin{array}{l}\text { Engelbert J. Dockner, } \\
\text { Manuel Mayer, } \\
\text { Josef Zechner }\end{array}$ & 217 & Sovereign Bond Risk Premiums \\
\hline $\begin{array}{l}\text { December 1, } \\
2017\end{array}$ & $\begin{array}{l}\text { Stefan Niemann, } \\
\text { Paul Pichler }\end{array}$ & 218 & $\begin{array}{l}\text { Optimal fiscal policy and sovereign debt } \\
\text { crises }\end{array}$ \\
\hline $\begin{array}{l}\text { January 17, } \\
2018\end{array}$ & Burkhard Raunig & 219 & $\begin{array}{l}\text { Economic Policy Uncertainty and the } \\
\text { Volatility of Sovereign CDS Spreads }\end{array}$ \\
\hline $\begin{array}{l}\text { February 21, } \\
2018\end{array}$ & $\begin{array}{l}\text { Andrej Cupak, } \\
\text { Pirmin Fessler, } \\
\text { Maria Silgoner, } \\
\text { Elisabeth Ulbrich }\end{array}$ & 220 & $\begin{array}{l}\text { Exploring differences in financial literacy } \\
\text { across countries: the role of individual } \\
\text { characteristics and institutions }\end{array}$ \\
\hline $\begin{array}{l}\text { May 15, } \\
2018\end{array}$ & $\begin{array}{l}\text { Peter Lindner, } \\
\text { Axel Loeffler, } \\
\text { Esther Segalla, } \\
\text { Guzel Valitova, } \\
\text { Ursula Vogel }\end{array}$ & 221 & $\begin{array}{l}\text { International monetary policy spillovers } \\
\text { through the bank funding channel }\end{array}$ \\
\hline
\end{tabular}

